\title{
Hematopoietic and Lymphoid System Neoplasm
}

National Cancer Institute

\section{Source}

National Cancer Institute. Hematopoietic and Lymphoid System Neoplasm. NCI

Thesaurus. Code C35813.

Neoplasms of the hematopoietic system, including hematopoietic cell neoplasms (e.g. leukemias, lymphomas) and non-hematopoietic cell neoplasms that can affect the hematopoietic system (e.g. lymph node and splenic sarcomas). --2003 